\title{
Street lighting power reduction potential in Lithuanian cities
}

\author{
R. Balsys ${ }^{1}$, K. Otas ${ }^{1}$, A. Mikulionis ${ }^{1}$, V. J. Pakènas ${ }^{1}$, A. Vaškys ${ }^{1}$, \\ P. Vitta ${ }^{2}$ \& A. Žukauskas ${ }^{2}$ \\ ${ }^{I}$ Department of Electrical Engineering, \\ Kaunas University of Technology, Lithuania \\ ${ }^{2}$ Institute of Applied Research, Vilnius University, Lithuania
}

\begin{abstract}
Purpose of this paper is to evaluate the current street lighting condition and energy saving possibilities using new light emitting diode (LED) technologies in the main cities of Lithuania. The power consumption evaluation model has been used for comparison of current high-pressure sodium (HPS) lamp technology and available LED technologies. The model enables to evaluate luminous flux losses as well as electric power losses. The calculations have been carried out for the largest Lithuanian cities and the following conclusions have been made. The current HPS technology was implemented in towns about $10-15$ years ago. Now the life time of those luminaries is being expired. So the renovation of street lighting systems would be necessary in the nearest future. It was determined that the implementation of LED technologies (due to higher efficiency of LEDs, smaller energy losses in luminaire optics, more effective distribution of luminous flux and other advantages) enables to achieve electric power reduction by 20 $60 \%$. This mostly depends on power of the HPS lamp to be replaced and the quality of LED luminaires. The expedience of the current luminaire replacement by LED luminaire depends on the street lighting condition characteristics such as type and power of luminaire, maintenance duration and others. Most energy efficient replacement by LED luminaires should be carried out in the narrow residential streets where luminance levels exceed the requirements of standards now.
\end{abstract}

Keywords: street lighting, power reduction, LED lighting. 


\section{Introduction}

A certain electric power of lighting system is being consumed to produce some useful luminous flux for city street lighting. The efficiency of the whole street lighting system may be evaluated using ratio of useful luminous flux for street lighting to required electric power of lighting system for production of the mentioned flux. This criterion may be used either for comparison of different street lighting systems $[1,2]$ or for the estimation of power reduction potential of renovated street lighting. The efficiency of street lighting system is determined by luminous flux losses as well as electric power losses that depend on technical parameters and quality of lighting system particular components. The engineering factor i.e. capability of optimum choice and use of possible street lighting technologies is of great importance too.

\section{Estimation of street lighting system efficiency}

The efficiency of street lighting system is closely related to losses emerging during conversion of electric energy into useful light energy. They are caused by electric and luminous energy transmission, transformation, conversion and distribution and also due to particularity of light source radiation spectrum. Engineering decisions for lighting system also have influence to efficiency. Analysing street lighting system efficiency it is expedient to distinguish luminous flux utilization efficiency, light source luminous efficacy and electric power supply efficiency.

\subsection{Luminous flux losses}

The useful luminous flux $\left(\Phi_{e}\right)$ incident on road surface should ensure the road surface luminance value according to the standards [3]. A part of luminaire luminous flux $\left(\Phi_{d}\right)$ uselessly dissipates into environment making losses. Dissipation loss factor evaluates this part of luminous flux:

$$
C_{d}=\Phi_{d} / \Phi_{e}
$$

The value of this factor depends on luminaire luminous intensity distribution and luminaire position with respect to the road and can change in wide range. In a similar way the light flux losses in luminaire optical system have been evaluated by means of optical system loss factor $\left(C_{o}\right)$. Furthermore during maintenance the optical properties of luminaries depreciate making extra luminous flux losses that usually are being taken into account in design stage and in this article they have been evaluated using factor $\left(C_{p}\right)$. All these factors increase the required initial light flux of light sources $\left(\Phi_{s}\right)$ that may be expressed:

$$
\Phi_{s}=\Phi_{e}\left(1+C_{d}\right)\left(1+C_{o}\right)\left(1+C_{p}\right)
$$


The luminous flux loss factor values of street lighting system are being defined according to luminaire technical characteristics and street lighting condition i.e. spacing, luminaire installation height, street width and the combination of the mentioned parameters. The reduction of luminous flux losses may be achieved using ingenious engineering decisions and their proper implementation. The luminaire optical system quality and maintenance conditions have influence on these factors.

\subsection{Light source efficiency}

Light source luminous efficacy $\left(\eta_{s}\right)$ has essential influence on the efficiency of the whole street lighting system. Up to now the changes of street lighting technologies from incandescent lamp to high-pressure mercury vapour lamp and further to high-pressure sodium vapour lamp enabled to increase lamp luminous efficacy more than twice. It was the main reason that enabled to reduce the street lighting system power since light source power $\left(P_{s}\right)$ :

$$
P_{s}=\Phi_{s} / \eta_{s}
$$

Upcoming LED technologies also predict similar achievements in the nearest future [1]. Since LED technology also has other advantages. So the best versions of LED technology may already successfully compete.

Light source luminous efficacy decreases during maintenance and causes the same depreciation in luminous flux assuming that the source power is constant. Due to the mentioned depreciation the source power use is increased at the initial maintenance stage. Dimming possibility enables to reduce lighting system power $\left(P_{m}\right)$ at the initial maintenance stage.

\subsection{Electric power losses}

These losses emerge due to energy losses in lamp supply circuits and electric energy supply network. HPS lamp luminaires including standard electromagnetic ballasts and separate street lighting electrical network are being used in the lighting systems of the main Lithuanian cities. A part of luminaires are being supplied through group power regulators (dimmers) varying voltage value. So electric power losses emerge in light source ballasts or supply electric circuits $\left(P_{b}\right)$, in electric power network $\left(P_{n}\right)$ and in group dimmers $\left(P_{c}\right)$ if they are being in use. In this article the losses mentioned above have been estimated by the correspondent loss factors $C_{b}, C_{n}$ and $C_{c}$. The power consumed by street lighting system has been calculated according to the equation:

$$
P=P_{s}\left(1+C_{b}\right)\left(1+C_{n}\right)\left(1+C_{c}\right)
$$


Such loss calculation method enables to show the influence of each loss component on the whole lighting system efficiency. Using expressions (2), (3) and (4) it may be calculated:

$$
\eta=\Phi_{e} / P
$$

These expressions may be quite precisely applied for the separate parts of lighting system that have equal and known parameters and the mentioned loss factors are quite exactly determined. For example, for the certain type and the same power HPS lamp luminaries installed and maintained under the same conditions. Many different luminaires are being maintained in the Lithuanian city lighting systems. So it is expedient to use the generalized statistical average values of loss factor applied to luminaires of the certain power following the whole lighting system division into parts according to HPS luminaire power. Similarly the LED luminaires of the same parameters should be grouped. For example, luminous efficacy of different spectrum LEDs differs considerably so they should be divided into separate groups.

\section{Current street lighting of Lithuanian cities}

During last 10-15 years the HPS lamp luminaires have been implemented in street lighting of Lithuanian cities and metal halide luminaires are being in use for architectural or pedestrian zone lighting. The other type luminaires such as fluorescent, mercury or incandescent make very small part and are being in use for underground crossing lighting or are still have not been replaced yet. Building of new streets or reconstruction usually includes lighting design and luminaire installation on special poles according to the European standards [3]. However during renovation of street lighting in residential districts with individual houses the aerial electric network reinforced-concrete poles are being used as lighting poles too. Their spacing is not suitable for lighting purposes so considerable light flux losses emerge.

\subsection{Light system characteristics of the largest cities}

Lighting systems of five largest Lithuanian cities (capital Vilnius, Kaunas, Klaipèda, Šiauliai and Panevėžys) have been analysed in this work. Their inhabitant number makes about $40 \%$ of that of Lithuania. The lighting system luminaire parameters of vehicle traffic streets are presented in table 1 . The luminaires for other lighting purposes i.e. for lighting of pedestrian zones, parks, underground crossings, objects of architecture are not included. More than $98 \%$ of street lighting luminaires in these cities make the high-pressure sodium lamp luminaires. The total power of the mercury lamp luminaires in the mentioned cities is only $292 \mathrm{~kW}$ or about $2 \%$ of the total power of the lighting systems. 
Table 1: $\quad$ Lighting system characteristics of Lithuanian cities.

\begin{tabular}{|c|c|c|c|c|c|}
\hline City & $\begin{array}{c}\text { Number of } \\
\text { inhabitants, } \\
\text { (thousands) }\end{array}$ & $\begin{array}{c}\text { Area, } \\
\left(\mathrm{km}^{2}\right)\end{array}$ & $\begin{array}{c}\text { Length of } \\
\text { lightened } \\
\text { streets }(\mathrm{km})\end{array}$ & $\begin{array}{c}\text { Quantity of } \\
\text { luminaires } \\
(\mathrm{pcs})\end{array}$ & $\begin{array}{c}\text { Power of } \\
\text { luminaires } \\
(\mathrm{kW})\end{array}$ \\
\hline Vilnius & 549 & 401 & 691 & 36696 & 5194 \\
\hline Kaunas & 349 & 157 & 807 & 24214 & 3227 \\
\hline Klaipėda & 183 & 98 & 563 & 13273 & 2204 \\
\hline Šiauliai & 125 & 88 & 280 & 11481 & 1601 \\
\hline Panevėžys & 112 & 50 & 270 & 7150 & 797 \\
\hline
\end{tabular}

\subsection{Condition of city lighting systems}

The development of street lighting during last 15-20 years has been analogous in all Lithuanian cities. Since formerly energy has not been saved, the $250 \mathrm{~W}$ power mercury lamp luminaires and also incandescent lamp luminaires have been used almost in all the streets. The city municipalities have been incapable to pay electric energy charges and street lighting has been switched on only part of the night time. In addition the considerable lighting power overloaded the street lighting electrical network caused frequent network failures increasing maintenance expenses. Therefore in order to ensure street lighting during entire dark time of night the decision to decrease the lighting system power has been made. Vilnius city commenced the replacement of mercury lamp luminaires the first. Kaunas and other cities followed a little later.

\subsubsection{Street lighting of Vilnius city}

In Vilnius the inefficient and quite powerful mercury lamp luminaires have been replaced by HPS lamp luminaires 15 years ago. Lighting control and electrical network have not been changed. So the possibilities of power decrease became insignificant and energy saving has been carried out by switching off one phase at night. Thus the power of $3743 \mathrm{~kW}$ lighting system part has been decreased about $1250 \mathrm{~kW}$ at night. However such an energy saving inadmissibly deteriorates the quality of street lighting. Carrying out the last renewal the quality of installed luminaires has not been the best. Consequently the new renovation of Vilnius street lighting system already is necessary.

\subsubsection{Street lighting of Kaunas city}

Kaunas street lighting system has been renovated later. Ten years ago the major part of mercury lamp luminaires has been replaced by sodium lamp luminaires having carried out lighting engineering and electrical network design. However the major part of electrical network has not been renewed. After renovation the halved power has been consumed although due to the lack of funds a part of luminaires $(232 \mathrm{~kW}$ or about $7 \%$ ) still has not been replaced. The lighting system power having been reduced in Kaunas city no luminaires have been switched off at night. In 2010 year street lighting in Kaunas city neither has not been dimmed nor switched off at night since electric energy consumption after renovation has been reduced $[5,6]$. 


\subsubsection{Street lighting of other cities}

In Klaipèda, Šiauliai and Panevėžys almost all streets are being lightened with HPS lamp luminaires. Only in Šiauliai city 103 mercury lamp luminaires are in use. Their total power is $14 \mathrm{~kW}$ and does not reach $1 \%$ of the street lighting system total power. Power reduction at night is being carried out by switching off a part of luminaires or using group dimmers that change the supply voltage. The data are presented in table 2 .

Table 2: $\quad$ Power reduction of lighting system.

\begin{tabular}{|c|c|c|}
\hline City & $\begin{array}{c}\text { Power of dimmed luminaires } \\
(\mathrm{kW})\end{array}$ & $\begin{array}{c}\text { Power of luminaires being } \\
\text { switched off }(\mathrm{kW})\end{array}$ \\
\hline Klaipėda & 940 & 524 \\
\hline Šiauliai & - & 800 \\
\hline Panevėžys & 319 & 314 \\
\hline
\end{tabular}

\section{Evaluation of lighting system efficiency}

Lighting system efficiency has been evaluated by ratio of street lighting useful luminous flux to lighting system power necessary for generation of the mentioned flux. The assumed value of the useful luminous flux in this work has been $1000 \mathrm{~lm}$. The electric power required for the generation of this flux has been deduced having taken into account the possible luminous flux losses, light source luminous efficacy and electric losses evaluated by means of factors described above. For this purpose the lighting system model has been made ensuring a possibility to vary the factors of losses under consideration according to the current parameters of lighting system. The lighting systems including the mercury QE $(80,125$ and $250 \mathrm{~W})$ lamp and sodium ST (70, 100, 150, 250 and

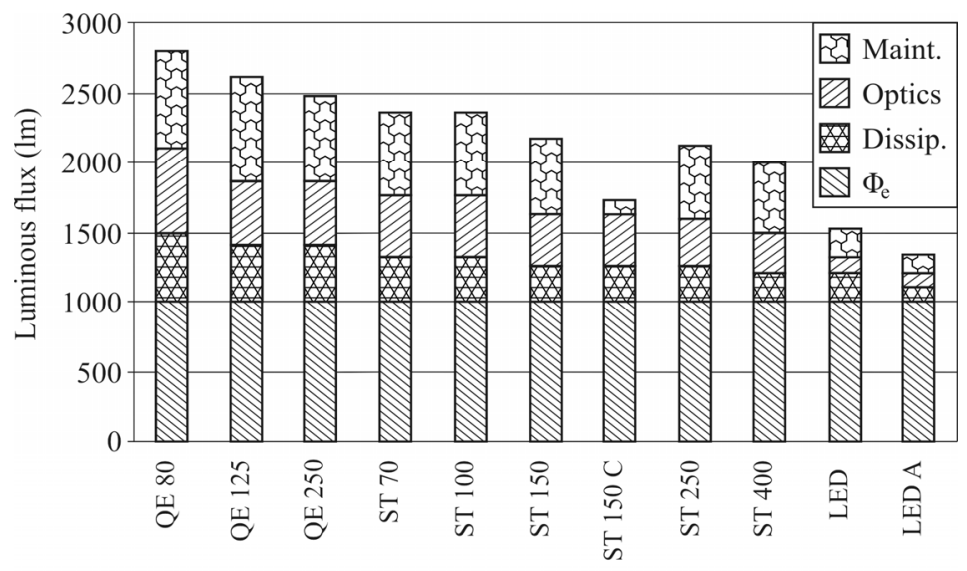

Lighting system

Figure 1: Light source luminous flux distribution dependent on lighting system. 
$400 \mathrm{~W}$ ) lamp luminaires without dimming have been analysed. The system including $150 \mathrm{~W}$ sodium lamp luminaires supplied from group dimmers (version ST $150 \mathrm{C}$ ) also have been under consideration. Using the same procedure two new lighting systems i.e. average level present-day LED lighting system (LED) and possible advanced LED lighting system (LED A) have been analysed.

The comparable calculation results of lamp luminous flux necessary to have useful flux of $1000 \mathrm{~lm}$ according to the dependence (2) are presented in Fig. 1. The comparable calculation results of electric power necessary to produce the same useful flux according to the dependence (4) are presented in Fig. 2.

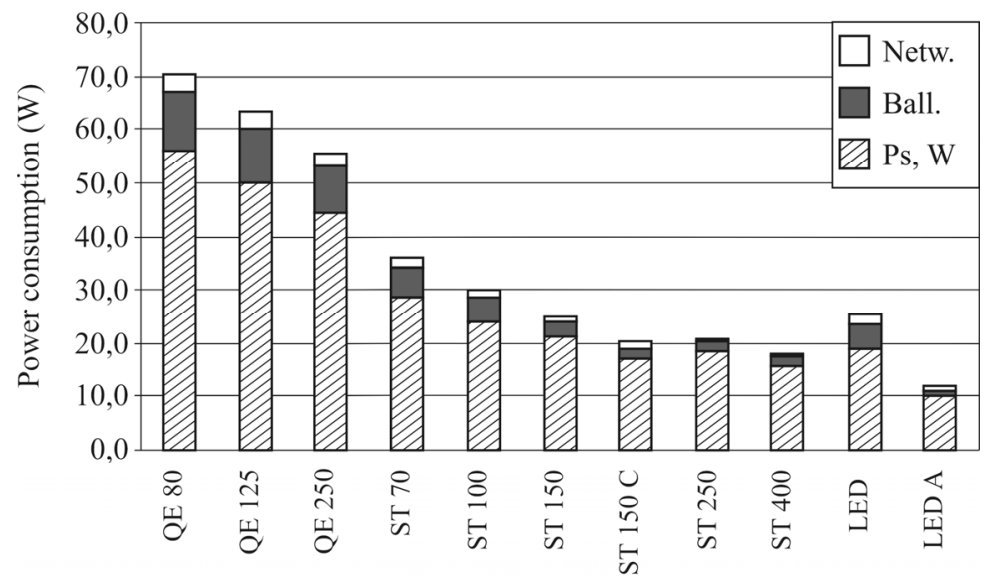

Lighting system

Figure 2: Dependence of consumed power to produce useful $1000 \mathrm{~lm}$ flux on lighting system.

Efficiency of street lighting system including HPS luminaires considerably depends on installed lamp power. The more powerful lamp unit the less electric power is required to produce the same amount of useful luminous flux.

This is caused by increased lamp luminous efficacy, reduced luminous flux dissipation losses and energy losses in ballast. The efficiency of LED lighting systems does not depend on power of luminaire unit since it is collected varying the separate small power LED number. LED lighting systems enable to reduce luminous flux losses and their rapid development also reduces losses in supply circuits that have been estimated as ballast losses in this work. Light source luminous efficacy has the main importance in LED lighting systems. It changes recently very rapidly and its value should be specified evaluating lighting system efficiency. In this work the luminous efficacy of LED has been assumed equal to $80 \mathrm{~lm} / \mathrm{W}$ (case LED) and $130 \mathrm{~lm} / \mathrm{W}$ (case LED A).

As it is shown above the major part of Lithuanian city lighting systems includes sodium lamps and only a small part includes mercury lamps. The possibilities of power reduction in separate Lithuanian cities by using of LED lighting technologies during lighting system renovation have been estimated by means of comparable calculation results within the current situation. The extra 
power reduction possibilities by dimming at night have not been analysed in this work.

Evaluation results show the current average quality LED technologies enable to reduce lighting system power only if mercury lamp luminaires or low power (70 or $100 \mathrm{~W}$ ) sodium lamp luminaries are being replaced. Even replacement of $150 \mathrm{~W}$ sodium lamp luminaires does not reduce system power especially if group dimmers have been used. For the current city lighting system structure the result of total power reduction is negative too (Table 3 ).

Table 3: Luminaire power consumption reduction by using of LED technologies in Lithuanian cities (for all considered cities).

\begin{tabular}{|c|c|c|c|c|c|c|}
\hline \multirow{2}{*}{ Lamps } & \multirow{2}{*}{$\begin{array}{c}\text { Quantity of } \\
\text { luminaires }\end{array}$} & \multirow{2}{*}{$\begin{array}{c}\text { Power } \\
(\mathrm{kW})\end{array}$} & \multicolumn{2}{|c|}{$\begin{array}{c}\text { Power reduction } \\
\text { (LED case) }\end{array}$} & \multicolumn{2}{c|}{$\begin{array}{c}\text { Power reduction } \\
\text { (LED A case) }\end{array}$} \\
\cline { 5 - 7 } & & & $\mathrm{kW}$ & $\%$ & $\mathrm{~kW}$ & $\%$ \\
\hline ST 70 & 41043 & 3376,3 & 881,0 & 26,1 & 2186,2 & 64,8 \\
\hline ST 100 & 9194 & 1060,7 & 117,6 & 11,1 & 610,9 & 57,6 \\
\hline ST 150 & 28951 & 4879,3 & $-631,1$ & $-12,9$ & 2251,2 & 46,1 \\
\hline ST 250 & 11189 & 3086,8 & $-843,4$ & $-27,3$ & 1212,3 & 39,3 \\
\hline ST 400 & 842 & 368,3 & $-180,2$ & $-48,9$ & 106,7 & 29,0 \\
\hline QE 80 & 186 & 16,6 & 10,3 & 62,0 & 13,6 & 81,9 \\
\hline QE 125 & 685 & 97,6 & 56,3 & 57,7 & 77,9 & 79,8 \\
\hline QE 250 & 498 & 132,9 & 69,2 & 52,1 & 102,5 & 77,1 \\
\hline Total & 92588 & 13018,5 & $-520,3$ & $-4,0$ & 6561,3 & 50 \\
\hline
\end{tabular}

Results of the current city street lighting system replacement by LED A (advanced) technology luminaires show that for all luminaire unit power cases the system power reduction has been obtained and the average power reduction has reached $50 \%$.

Analysing the separate cities (table 4) it can be seen that implementation of the current LED technologies is not useful for Klaipeda city since there are no mercury lamps there and considerable part of luminaires $(940 \mathrm{~kW})$ is being supplied from group dimmers. Only in Kaunas city this technology enables to reduce the lighting system power by $119 \mathrm{~kW}$. In the rest cities the possibilities of power reduction are negative.

Table 4: Luminaire power consumption reduction by using of LED technologies in separate Lithuanian cities.

\begin{tabular}{|c|c|c|c|c|}
\hline \multirow{2}{*}{ City } & \multicolumn{2}{|c|}{ Power reduction (LED case) } & \multicolumn{2}{c|}{ Power reduction (LED A case) } \\
\cline { 2 - 5 } & $\mathrm{kW}$ & $\%$ & $\mathrm{~kW}$ & $\%$ \\
\hline Vilnius & $-178,4$ & $-3,4$ & 2632 & 50,7 \\
\hline Kaunas & 118,9 & 3,7 & 1745 & 54,1 \\
\hline Klaipėda & $-438,2$ & $-19,9$ & 944 & 42,8 \\
\hline Šiauliai & $-1,4$ & $-0,1$ & 837 & 52,3 \\
\hline Panevěžys & $-7,1$ & $-0,9$ & 414 & 51,9 \\
\hline
\end{tabular}


Another result would be obtained using advanced LED A technologies. In this case all the Lithuanian cities could reduce street lighting system power about two times. Relatively the power could be reduced mostly in Kaunas city (54\%) and the least effect would be in Klaipèda (42\%).

\section{Conclusions}

Proposed street lighting system efficiency evaluation model enabled to carry out the current street lighting system analysis for the largest Lithuanian cities and to estimate their efficiency. Street lighting system power reduction potential using the current average quality LED technologies and the advanced LED A technologies have been analysed. It is determined the current LED technologies enable to reduce the lighting system power by replacing mercury lamp luminaires or low power $(70$ or $100 \mathrm{~W})$ sodium lamp luminaires only. Considering the current street lighting system structure of main Lithuanian cities, the total system power could not be reduced using average quality LED technology. The lighting system power reduction by approximately $50 \%$ is possible using advanced LED A technology only.

\section{Acknowledgement}

This research was funded by a grant (No. ATE-09/2010) from the Research Council of Lithuania.

\section{References}

[1] Eclairage public, Recommandations aux authorites communales et aux exploitants de reseaux d'eclairage http://www.energieeffizienz.ch/files/SB Flyer_2009_f.pdf

[2] Gestion et LED, Eclairage public, Recommandations aux authorites communales et aux exploitants de reseaux d'eclairage http://www.energieeffizienz.ch/files/SB_Flyer_2010_f.pdf

[3] EN 13201-2:2003, Road lighting - Part 2: Performance requirements, p 20.

[4] LEDs: roadmap pour les annees a venir, http://www.led-fr.net/led-roadmap2010022510106.htm.

[5] Balsys, Ramūnas; Mikulionis, Albertas; Pakènas, Valdas Jonas; Vaškys, Alfonsas. Prospects of renovation of the Kaunas street lighting system//Electrical and Control Technologies - 2006 : selected papers of the international conference, May 4-5, 2006, Kaunas, Lithuania. - ISSN 1822-5934. -Kaunas. -2006, p. 114-118.

[6] Balsys, Ramūnas; Mikulionis, Albertas; Pakenas, Valdas Jonas; Vaškys, Alfonsas. Possibilities of renovation of Kaunas street lighting // Electrical and Control Technologies - 2007 : selected papers of the 2nd international conference, May 3-4, 2007, Kaunas, Lithuania /. - ISSN 1822-5934. Kaunas. - 2007, p. 163-166. 